\title{
Educating Dental Students About Diet- Related Behavior Change: Does Experiential Learning Work?
}

\author{
George W. Taylor, D.M.D., Dr.P.H.; Madelyn L. Stumpos, B.A.; Wendy Kerschbaum, \\ R.D.H., M.P.H.; Marita Rohr Inglehart, Dr. phil. habil.
}

Abstract: The objective of this study was to explore whether an experiential exercise in a nutrition class would a) increase dental students' motivation to change their own diet-related behavior, b) improve their understanding of theoretical concepts related to behavior change, and c) improve their attitudes towards educating their patients about diet-related behavior. Data were collected from 218 senior dental students in one dental school (2010: 106; 2011: 112) during their nutrition class. The students agreed at the beginning that it was important to change their own diet-related behavior. After one week, the majority agreed that they had changed how they felt and thought about the targeted behavior and what they actually did. After three weeks and at the end of the term, they rated the exercise as helpful for gaining a better understanding of health education theories. The majority indicated that the exercise had helped them understand the difficulty of diet-related behavior change and that it had increased their interest in helping patients change their diet-related behavior. In conclusion, this study suggests that experiential learning about diet-related behavior change is likely to affect students' own behavior positively and to result in increased understanding of behavior change theories and positive behavioral intentions concerning future health education efforts with patients.

Dr. Taylor is Chair, Department of Preventive and Restorative Dental Sciences, University of California, San Francisco School of Dentistry; Ms. Stumpos is a first-year dental student, University of Michigan School of Dentistry; Ms. Kerschbaum is Program Director Emeritus, Dental Hygiene Program, University of Michigan School of Dentistry; and Dr. Inglehart is Professor, Department of Periodontology and Oral Medicine, University of Michigan School of Dentistry and Adjunct Professor, Department of Psychology, College of Literature, Science of Arts, University of Michigan. Direct correspondence and requests for reprints to Dr. Marita R. Inglehart, Department of Periodontology and Oral Medicine, School of Dentistry, University of Michigan, 1011 North University Ave., Ann Arbor, MI 48109-1078; 734-763-8073; mri@umich.edu.

Keywords: diet, nutritional management, dental education, dental students, behavior change, health education, motivational interviewing, transtheoretical model, experiential learning

Submitted for publication 9/16/12; accepted 2/7/13

$\mathrm{P}$ atients' diet-related behavior is integrally related to their oral and general health. ${ }^{1}$ As early as 1988, Burt et al. reported that a higher daily sugar intake during and between meals resulted in a relatively higher caries rate in children. ${ }^{2}$ More recent research provided additional evidence that sugar intake is one of the main risk factors for dental caries and that there is an association between the amount and frequency of consuming sugar and dental caries. ${ }^{3,4}$ Diet-related behavior can also be protective as shown by Kolker et al., who found that higher milk consumption was associated with lower caries rates. ${ }^{5}$ Other studies have reported that dairy products with no added sugar had cariostatic effects ${ }^{6,7}$ and even contributed to preventing caries and periodontal disease. ${ }^{8-10}$ While the evidence is limited concerning the relationship between the frequency of consuming meat and oral health, Laffranchi et al. found greater demineralization and more white spot lesions in adult vegans compared to adults with no dietary restrictions, ${ }^{11}$ and Sherfudhin et al. reported in their study with young adult Indian vegetarians that they had a higher degree of tooth wear, higher crowding, and other poor oral health effects compared to nonvegetarian subjects. ${ }^{12}$ In addition to the types of foods consumed, there are studies that have reported that children who did not eat breakfast daily or did not consume five servings of fruits and vegetables a day had a greater likelihood of experiencing caries and had more untreated decay. ${ }^{13,14}$ There is also sound evidence that a balanced diet facilitates remineralization and ossification and promotes healing and resistance to infections. ${ }^{15}$

These findings concerning the effects of constructive diet-related behavior for promoting patients' oral health ${ }^{16}$ point to the significance of educating future dental care providers about these issues and increasing their knowledge and skills concerning how to best educate their patients about these matters. It is therefore not surprising that diet-related 
health promotion efforts are explicitly referred to in the American Dental Education Association (ADEA) Foundation Knowledge and Skills for the New General Dentist. ${ }^{17}$ This document states that dental graduates must be competent in providing prevention, intervention, and educational strategies for promoting their patients' health and lists "nutrition" in connection with prevention strategy-related knowledge and skills.

In 2001, a survey of academic administrators in various health professions programs in the United States showed that administrators in dental schools were less likely to perceive a need to educate their students about how to counsel their patients about modifying their diet and how and when to refer their patients to a registered dietitian than administrators in the other programs..$^{18}$ More recently in 2010, Curran et al. reported that only 4.8 percent of the nearly 3,000 members of the American Dental Association who responded to a survey offered a form of obesity nutrition counseling, but that 50.5 percent said they were interested in offering obesity-related counseling and 82 percent agreed they would be more willing to intervene if obesity were linked definitively to oral disease.${ }^{19}$ Providing these dentists with the foundation knowledge and skills concerning the relationship among diet-related behavior, obesity, and oral health ${ }^{20}$ and how to best educate patients about these issues seems therefore crucial.

In consideration of the rise in childhood obesity in the United States, ${ }^{21,22}$ these efforts seem especially important when providing care for pediatric dental patients. However, Braithwaite et al. reported in 2008 that less than 25 percent of pediatric dentists in North Carolina provided nutrition counseling services. ${ }^{23}$ The fact that these researchers also found that academic preparation about these issues during the pediatric dentists' residency programs was significantly related to their actual professional behavior further illustrates the importance of identifying how to best integrate education about nutrition and diet into dental and dental hygiene curricula.

In consideration of these previous findings, the question arises how to best educate dental and dental hygiene students about nutrition, diet, and oral health. One frequently discussed theme in this context is the issue of integrating the material about nutrition and diet into the basic and clinical science lectures related to these issues..$^{24-26} \mathrm{~A}$ previous study analyzed the efficacy of different approaches to presenting the material, such as self-instructional programs versus traditional lectures. ${ }^{27}$ However, merely educating future dental care providers by providing them with the foundation knowledge concerning these issues in classroom-based settings neglects to ensure that these students have the awareness and attitudes needed to approach patients in a positive manner and the skills to engage patients successfully in constructive behavior change. For example, Magliocca et al. found in their survey of dental and dental hygiene students that 31 percent of these students had a negative attitude towards obese patients and 17 percent reported that it was difficult for them to have empathy for obese patients. ${ }^{28}$

One way to engage students more holistically in achieving a deeper understanding of the basic knowledge related to nutrition, diet, and oral health and in gaining the skills needed to successfully engage their patients in health education is to challenge them to work on diet-related behavior change in their own lives while participating in a class on these issues. An experiential exercise was therefore introduced into a nutrition course for senior dental students at one dental school in 2010 and then repeated with the senior students in 2011. Previous research with medical students showed that engaging students in diet- and exercise-related self-evaluations and change efforts while taking related courses increased confidence in their diet and exercise counseling skills and led to improvement in their own dietary habits. ${ }^{29,30}$ The purpose of our educational intervention was to explore whether an experiential exercise in a nutrition class for senior dental students would result in a) positive motivation to change their own diet-related behavior and positive evaluations of their success with changing their diet, b) improved understanding of the theoretical concepts related to health education and behavior change, and c) a positive attitude towards this type of health education for their future patients.

\section{Methods}

This study was approved by the Institutional Review Board for the Health and Behavioral Sciences at the University of Michigan. Data were collected from 106 senior dental students in the summer term 2010 and from 112 senior dental students in the summer term 2011.

At the beginning of the class, the students were informed that one assignment in this class was to participate in a three-week experiential exercise concerned with their own diet and a change in one self-identified diet-related behavior. The students 
participated in this exercise by responding to webbased assignments at the beginning of the exercise, after one week, after two weeks, and at the end of the exercise. The web-based surveys consisted of open- and closed-ended questions. The open-ended answers required students to indicate which behavior they intended to change (see Table 1) and to provide explanations for some of their closed-ended answers. The closed-ended questions were mostly answered on five-point rating scales (see Tables 2, 3, 4, and 5 for exact wording of the answer categories).

This experiential exercise was part of a nineweek class for senior dental students during the summer term in 2010 and 2011. A review session about the theories of behavior change and patient education was provided as an introduction to the exercise. This review focused on the A-B-C model of behavior change ${ }^{31}$ (see Figure 1), the transtheoretical behavior change model, ${ }^{32}$ and the theory of motivational interviewing. ${ }^{33}$ The students' first weekly assignment at the beginning of week 1 was to decide on one diet-related behavior in themselves they wanted to change and to reflect on why they wanted to change this behavior, which challenges they might encounter, and how their own behavior change was related to the A-B-C model of change ${ }^{31}$ and the transtheoretical model of change. ${ }^{32}$ The A-B$\mathrm{C}$ model of change ${ }^{31}$ allowed them to reflect on how they felt about the behavior change ( $\mathrm{A}=\mathrm{Affect})$, on their current and past behavior related to the intended behavior change ( $\mathrm{B}=$ Behavior), and their thoughts, beliefs, and expectations $(\mathrm{C}=$ Cognition) about this change. The transtheoretical model ${ }^{32}$ challenged them to consider in which stage of change they were (precontemplation, contemplation, preparation, action, or maintenance) and to which stage of change they wanted to progress from week to week. Following this assignment, they engaged in the diet changes over a one-week time span.

At the beginning of week 2 of the class, the students were asked to reflect in their second web-based assignment on the progress they had made with their

Table 1. Comparisons of student responses in 2010 and 2011 to question "Which behavior do you want to change?" at baseline

\begin{tabular}{|c|c|c|c|}
\hline Answer Category & $\begin{array}{c}2010 \\
N=106\end{array}$ & $\begin{array}{c}2011 \\
N=112\end{array}$ & Both Years \\
\hline Eating less unhealthy food-SUM & $50(47 \%)$ & $41(37 \%)$ & $91(42 \%)$ \\
\hline Less junk/fast food/snacking & 14 & 21 & 35 \\
\hline Reduce sugar intake/fewer sweets & 9 & 7 & 16 \\
\hline Stop pop/coffee/caffeine/Gatorade & 9 & 5 & 14 \\
\hline Reduce portion sizes & 9 & 4 & 13 \\
\hline Fewer carbohydrates & 7 & 2 & 9 \\
\hline Weight & 2 & 0 & 2 \\
\hline Less salt/sodium & 0 & 2 & 2 \\
\hline Eating more healthy food-SUM & $56(53 \%)$ & $30(27 \%)$ & $86(39 \%)$ \\
\hline More vegetables & 18 & 10 & 28 \\
\hline Eating healthy diet & 17 & 9 & 26 \\
\hline More fruit & 7 & 9 & 16 \\
\hline More water & 6 & 1 & 7 \\
\hline Increase protein & 5 & 0 & 5 \\
\hline Take daily vitamin & 2 & 0 & 2 \\
\hline More fiber & 1 & 1 & 2 \\
\hline Eat at different times-SUM & $18(17 \%)$ & $40(36 \%)$ & $58(27 \%)$ \\
\hline Eat at right times/more regularly & 7 & 17 & 24 \\
\hline Eating out/eating style & 4 & 7 & 11 \\
\hline Eating more frequently & 4 & 3 & 7 \\
\hline Eating habits & 2 & 12 & 14 \\
\hline Afternoon snacks & 1 & 1 & 2 \\
\hline Lifestyle change-SUM & $7(7 \%)$ & $7(6 \%)$ & $14(6 \%)$ \\
\hline Exercise more & 5 & 7 & 12 \\
\hline Quit smoking & 1 & 0 & 1 \\
\hline Less alcohol consumption & 1 & 0 & 1 \\
\hline
\end{tabular}


Table 2. Comparisons of average responses in 2010 and 2011 concerning students' motivation for change at baseline, after one week, and after two weeks

\begin{tabular}{|c|c|c|c|c|c|}
\hline Motivational Indicator & Year & $\begin{array}{c}\text { A1: } \\
\text { Baseline } \\
\text { Mean (SD) }\end{array}$ & $\begin{array}{c}\text { A2: After One } \\
\text { Week } \\
\text { Mean (SD) }\end{array}$ & $\begin{array}{c}\text { A3: After Two } \\
\text { Weeks } \\
\text { Mean (SD) }\end{array}$ & $\begin{array}{c}\mathrm{p}(\text { Year }) \\
\mathrm{p} \text { (Assignment) } \\
\mathrm{p}(\mathrm{Y} \times \mathrm{A})\end{array}$ \\
\hline \multirow{2}{*}{$\begin{array}{l}\text { How important would it be for your } \\
\text { health to change this behavior?a }\end{array}$} & 2010 & $3.90(0.797)$ & $4.09(0.888)$ & $3.87(0.840)$ & \multirow{2}{*}{$\begin{array}{c}p(Y)=0.022 \\
p(A)=0.020 \\
p(Y \times A)=0.524\end{array}$} \\
\hline & 2011 & $4.13(0.797)$ & $4.12(0.927)$ & $4.06(0.823)$ & \\
\hline \multirow{2}{*}{$\begin{array}{l}\text { How motivated are you to change } \\
\text { this behavior? }\end{array}$} & 2010 & $2.50(0.819)$ & $3.99(1.309)$ & - & \multirow{2}{*}{$\begin{array}{c}\mathrm{p}(\mathrm{Y})<0.001 \\
\mathrm{p}(\mathrm{A})<0.001 \\
\mathrm{p}(\mathrm{Y} \times \mathrm{A})<0.001\end{array}$} \\
\hline & 2011 & $3.92(0.818)$ & $3.30(1.309)$ & - & \\
\hline \multirow{2}{*}{$\begin{array}{l}\text { How easy/difficult will it be to } \\
\text { change this behavior? }\end{array}$} & 2010 & $2.93(0.860)$ & & & \multirow[t]{2}{*}{$\mathrm{p}(\mathrm{Y})=0.028$} \\
\hline & 2011 & $2.66(0.888)$ & & & \\
\hline \multirow[t]{2}{*}{ Which stage are you in now? ${ }^{c}$} & 2010 & $2.89(0.922)$ & $3.79(0.794)$ & & \multirow{2}{*}{$\begin{array}{c}p(Y)=0.671 \\
p(A)<0.001 \\
p(Y \times A)=0.698\end{array}$} \\
\hline & 2011 & $2.79(0.812)$ & $3.67(0.737)$ & & \\
\hline \multirow[t]{2}{*}{ Which stage do you want to be in? ${ }^{c}$} & 2010 & $4.13(0.821)$ & & & \multirow[t]{2}{*}{$p(Y)=0.701$} \\
\hline & 2011 & $4.17(0.755)$ & & & \\
\hline
\end{tabular}

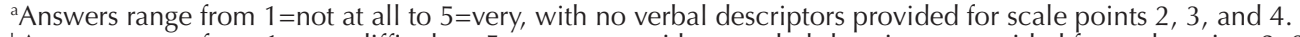

${ }^{\mathrm{b}}$ Answers range from $1=$ very difficult to $5=$ =very easy, with no verbal descriptors provided for scale points 2,3 , and 4 .

cAnswers range from $1=$ precontemplation, $2=$ contemplation, $3=$ preparation, $4=$ action to $5=$ maintenance.

Notes: The p(Year) value refers to the significance level of the main effect "Year" with the levels "2010" and "2011." The p(Assignment) value refers to the significance level of the main effect "Assignment" with the levels "Baseline," "One week assignment," and "Two week assignment." The $\mathrm{p}(\mathrm{Y} \times \mathrm{A})$ value refers to the significance level of the interaction effect between the two independent variables "Year" and "Assignment."

diet-related behavior change and to discuss how the four principles of the theory of motivational interviewing ${ }^{33}$ (creating a discrepancy, having empathy, rolling with resistance, and creating self-efficacy) were related to their progress. After a second week of engaging in efforts to change their chosen behavior, their third assignment at the beginning of week 3 asked them to reflect again on their progress and how the theories of behavior change related to it and to discuss how they could have been more successful. Finally, at the end of week 3 , they responded to a questionnaire assessing their behavior change and evaluating the intervention.

The data were analyzed with SPSS (Version 18). Descriptive statistics (e.g., frequencies and means) were computed to describe the responses. Inferential statistics such as chi-square tests, independent sample t-tests, and repeated measurement analyses of variance (ANOVAs) were used to compare the responses of the students in 2010 and 2011 as well as the responses at different time points in the term. A significance level of $\mathrm{p} \leq 0.05$ was accepted.

\section{Results}

Table 1 provides an overview of the responses in 2010 and 2011 concerning which behaviors the students targeted for the assignment. In 2010, twentyfive students reported two behaviors they wanted to change. The students in the following year were encouraged to choose only one behavior they wanted to change. However, six of the 112 students in 2011 again choose two behaviors.

The most frequent category of behavior change was concerned with behaviors related to eating less (Table 1). Fifty of the students in 2010 and forty-one of the students in 2011 reported that they wanted, in one way or another, to eat less or to eat fewer unhealthy foods. The most frequently named behavior targeted was to eat less junk food or fast food or to snack less. The next most frequently targeted behavior was a reduction in sugar intake and having fewer sweets as well as drinking fewer unhealthy beverages such as soda pop, coffee, drinks with caffeine, 
Table 3. Comparisons of students' responses in 2010 and 2011 concerning their success with changing targeted behavior

\begin{tabular}{|c|c|c|c|c|c|}
\hline Outcome Indicator & Year & $\begin{array}{c}\text { A2 } \\
\text { After Week } 1\end{array}$ & $\mathrm{p}$ & & \\
\hline \multirow{2}{*}{$\begin{array}{l}\text { Did you change how you feel about the } \\
\text { behavior? \% yes }\end{array}$} & 2010 & $63 \%$ & 0.185 & & \\
\hline & 2011 & $70 \%$ & & & \\
\hline \multirow[t]{2}{*}{ Did you change the behavior? \% yes } & 2010 & $69 \%$ & 0.313 & & \\
\hline & 2011 & $73 \%$ & & & \\
\hline \multirow{3}{*}{$\begin{array}{l}\text { Did you change how you think about } \\
\text { the behavior? \% yes }\end{array}$} & 2010 & $71 \%$ & 0.074 & & \\
\hline & 2011 & $80 \%$ & & & \\
\hline & Year & $\begin{array}{c}\text { A2 } \\
\text { After Week } 1\end{array}$ & $\begin{array}{c}\text { A3 } \\
\text { After Week } 2 \\
\end{array}$ & End Survey & $\begin{array}{l}p(\text { Year }) \\
p(\text { Assignment }) \\
p(Y \times A)\end{array}$ \\
\hline \multirow{2}{*}{$\begin{array}{l}\text { Rate the degree of success you had dur- } \\
\text { ing the last week. }{ }^{\text {a Mean (SD) }}\end{array}$} & 2010 & $6.68(2.108)$ & $6.92(1.925)$ & $6.48(1.920)$ & $p(\mathrm{Y})=0.890$ \\
\hline & 2011 & $6.28(2.118)$ & 7.04 (1.917) & $6.844(2.080)$ & $\begin{array}{c}\mathrm{p}(\mathrm{A})<0.001 \\
\mathrm{p}(\mathrm{Y} \times \mathrm{A})=0.058\end{array}$ \\
\hline \multirow{2}{*}{$\begin{array}{l}\text { How much self-efficacy concerning } \\
\text { change do you have now? }{ }^{\text {b }} \text { Mean (SD) }\end{array}$} & 2010 & $3.73(0.718)$ & - & - & $p(Y)=0.125$ \\
\hline & 2011 & $3.88(0.781)$ & - & - & \\
\hline \multirow{2}{*}{$\begin{array}{l}\text { How confident do you feel about being } \\
\text { able to make the change?c Mean (SD) }\end{array}$} & 2010 & - & $3.74(0.772)$ & - & $p(Y)=0.521$ \\
\hline & 2011 & - & $3.79(0.773)$ & - & \\
\hline \multicolumn{6}{|c|}{$\begin{array}{l}\text { answers range from } 1=\text { not successful to } 10=\text { very successful, with no verbal descriptors provided for scale points } 2 \text { to } 9 . \\
\text { bAnswers range from } 1=\text { none to } 5=\text { very high level, with no verbal descriptors provided for scale points } 2,3 \text {, and } 4 . \\
\text { cAnswers range from } 1=\text { not to } 5=\text { =very, with no verbal descriptors provided for scale points } 2,3 \text {, and } 4 \text {. }\end{array}$} \\
\hline \multicolumn{6}{|c|}{$\begin{array}{l}\text { Note: The } p \text { (Year) value refers to the significance level of the main effect "Year" with the levels "2010" and "2011." The p(Assignment) } \\
\text { value refers to the significance level of the main effect "Assignment" with the levels "Baseline," "One week assignment," and "Two } \\
\text { week assignment." The p(Y x A) value refers to the significance level of the interaction effect between the two independent variables } \\
\text { "Year" and "Assignment." }\end{array}$} \\
\hline
\end{tabular}

or sports drinks such as Gatorade. After eating less, the second most frequent group of targeted behaviors was to eat more healthily. Examples were to eat more vegetables or fruit, drink more water, increase protein intake, have a daily vitamin, or have more fiber. The third most frequently named category of behavior change was to eat at different times such as to eat at the right times or more regularly, not having an afternoon snack, or eating more frequently. Very few students choose a behavior related to a lifestyle change. Some students wanted to exercise more, but only one student wanted to quit smoking and one student reported less alcohol consumption as a goal.

Our first objective was to analyze the students' responses concerning their motivation to change their own diet-related behavior and their evaluations of their success with this targeted behavior change. At the beginning of the program, the students in both years reported that changing their chosen diet-related behavior was rather important for their own health (on a five-point scale from $1=$ not at all important to 5=very important: 3.90 in 2010 and 4.13 in 2011). After one week of behavior change, the importance ratings were about equally high (4.09 and 4.12, respectively), and after two weeks they were still seen as important (Table 2). Overall, the students in 2011 rated the importance of their chosen behavior change higher than the students in 2010 ( $\mathrm{p}=0.022)$.

The students in the class of 2010 reported an average motivation for behavior change of 2.50 on a five-point scale that ranged from $1=$ not at all motivated to $5=$ very motivated, while the students in 2011 reported being much more motivated $($ mean $=3.92)$ at baseline than the students in 2010 (Table 2). However, after one week, the students in the 2010 class were more motivated than at baseline (change from 2.50 to 3.99), while the students in the 2011 class reported being less motivated than at the beginning (change from 3.92 to 3.30; interaction effect: $\mathrm{p}<0.001)$. 
Table 4. Comparisons of value of exercise for increasing understanding of different theoretical approaches in 2010 vs. 2011

\begin{tabular}{|c|c|c|c|c|}
\hline Average Evaluations of Exercise for Understanding the ... & Year & $\begin{array}{c}\text { A3 } \\
\text { Mean (SD) }\end{array}$ & $\begin{array}{l}\text { End Survey } \\
\text { Mean (SD) }\end{array}$ & $\mathrm{p}$ (Year) \\
\hline \multicolumn{5}{|l|}{ Transtheoretical model } \\
\hline \multirow{2}{*}{$\begin{array}{l}\text { How helpful was the exercise in making you understand the } \\
\text { stage of change you were in at the beginning and after one } \\
\text { week? }\end{array}$} & 2010 & $3.26(1.084)$ & & \multirow{2}{*}{0.255} \\
\hline & 2011 & $3.44(1.204)$ & & \\
\hline \multirow{2}{*}{$\begin{array}{l}\text { How much did this assignment increase your understanding } \\
\text { of the transtheoretical model of change? }\end{array}$} & 2010 & & $3.22(1.038)$ & \multirow{2}{*}{0.438} \\
\hline & 2011 & & $3.11(1.070)$ & \\
\hline \multicolumn{5}{|l|}{ A-B-C model } \\
\hline \multirow{2}{*}{$\begin{array}{l}\text { How helpful was the exercise in making you understand } \\
\text { how you feel ( } A=\text { Affect), think ( } C=\text { Cognition), and what you } \\
\text { do? }\end{array}$} & 2010 & $3.63(0.933)$ & & \multirow{2}{*}{0.450} \\
\hline & 2011 & $3.72(0.855)$ & & \\
\hline \multirow{2}{*}{$\begin{array}{l}\text { How much did this assignment increase your understanding } \\
\text { of the A-B-C model of change? }\end{array}$} & 2010 & & $3.21(1.053)$ & \multirow{2}{*}{0.938} \\
\hline & 2011 & & $3.22(1.097)$ & \\
\hline \multicolumn{5}{|l|}{ Motivational interviewing (MI) } \\
\hline \multirow{2}{*}{$\begin{array}{l}\text { How helpful was the exercise in making you understand } \\
\text { the four aspects of MI (empathy/develop discrepancy/self- } \\
\text { efficacy/resistance)? }\end{array}$} & 2010 & $2.94(1.027)$ & & \multirow{2}{*}{0.097} \\
\hline & 2011 & $3.18(1.117)$ & & \\
\hline \multirow{2}{*}{$\begin{array}{l}\text { How much did this assignment increase your understanding } \\
\text { of MI as an approach to changing behavior? }\end{array}$} & 2010 & & $3.10(1.134)$ & \multirow{2}{*}{0.617} \\
\hline & 2011 & & $3.03(1.056)$ & \\
\hline \multirow{2}{*}{$\begin{array}{l}\text { How much did this assignment increase your understanding } \\
\text { of the concept of self-efficacy? }\end{array}$} & 2010 & & $3.29(0.948)$ & \multirow{2}{*}{0.444} \\
\hline & 2011 & & $3.18(0.993)$ & \\
\hline \multirow{2}{*}{$\begin{array}{l}\text { How much did this assignment increase your understanding } \\
\text { of the importance of creating discrepancy? }\end{array}$} & 2010 & & 3.19 (1.093) & \multirow{2}{*}{0.109} \\
\hline & 2011 & & $2.94(1.136)$ & \\
\hline \multirow{2}{*}{$\begin{array}{l}\text { How helpful was the assignment in helping you to get a } \\
\text { clearer sense of the concepts of different theories used for } \\
\text { creating behavior change? }\end{array}$} & 2010 & & $3.25(0.973)$ & \\
\hline & 2011 & & $3.17(1.110)$ & \\
\hline
\end{tabular}

At baseline, the students in both years thought that it would not be too difficult to change their behavior (on a five-point scale with $5=$ very easy: 2.93 in 2010 and 2.66 in 2011) (Table 2). When analyzing in which stage of change the students perceived themselves to be at baseline, the answers showed that on average the students perceived themselves to be between the contemplation stage and the preparation stage, but closer to the latter. With $1=$ precontemplation, $2=$ contemplation, and $3=$ preparation, the mean in 2010 was 2.89 , and the mean in 2011 was 2.79 . The students indicated that they wanted to be in an action stage. However, after one week, both groups of students were on average in an action stage.

Students' perceptions about how successful their behavior was varied over time. After one week, the majority of the students in both years indicated that they had changed how they felt about the behav- ior (2010: 63 percent; 2011: 70 percent), that they had changed the behavior itself (2010: 69 percent; 2011: 73 percent), and that they had changed how they thought about the behavior (2010: 71 percent; 2011: 80 percent) (Table 3 ). On a ten-point scale with $1=$ not successful at all, the students in both years evaluated themselves as being successful. However, while their evaluations slightly increased from the end of week 1 to the end of week 2 , the scores decreased slightly from the end of week 2 to the end of the term $(p<0.001)$. After one week, the students in both years were rather positive concerning their own self-efficacy, and after two weeks they were on average rather confident about being able to make the change.

The second objective of the study was to improve the students' understanding of the theoretical concepts related to health education and behavior 


\begin{tabular}{|c|c|c|c|c|c|c|c|}
\hline Question & Year & 1 & 2 & 3 & 4 & 5 & $\underset{p}{\text { Mean }(\mathrm{SD})}$ \\
\hline How interesting was the assignment? & $\begin{array}{l}2010 \\
2011\end{array}$ & $\begin{array}{l}8 \% \\
11 \%\end{array}$ & $\begin{array}{l}16 \% \\
19 \%\end{array}$ & $\begin{array}{l}49 \% \\
34 \%\end{array}$ & $\begin{array}{l}22 \% \\
32 \%\end{array}$ & $\begin{array}{l}5 \% \\
5 \%\end{array}$ & $\begin{array}{l}3.00(0.945) \\
3.01(1.066) \\
p=0.945\end{array}$ \\
\hline $\begin{array}{l}\text { How helpful was the assignment in making you } \\
\text { aware of the difficulty of behavior change? }\end{array}$ & $\begin{array}{l}2010 \\
2011\end{array}$ & $\begin{array}{l}3 \% \\
8 \%\end{array}$ & $\begin{array}{l}17 \% \\
18 \%\end{array}$ & $\begin{array}{l}29 \% \\
23 \%\end{array}$ & $\begin{array}{l}33 \% \\
39 \%\end{array}$ & $\begin{array}{l}18 \% \\
12 \%\end{array}$ & $\begin{array}{c}3.48(1.065) \\
3.29(1.129) \\
p=0.221\end{array}$ \\
\hline $\begin{array}{l}\text { How much insight did you gain into diet-related } \\
\text { behavior change through this assignment? }\end{array}$ & $\begin{array}{l}2010 \\
2011\end{array}$ & $\begin{array}{l}5 \% \\
9 \%\end{array}$ & $\begin{array}{l}16 \% \\
22 \%\end{array}$ & $\begin{array}{l}38 \% \\
30 \%\end{array}$ & $\begin{array}{l}31 \% \\
34 \%\end{array}$ & $\begin{array}{l}11 \% \\
6 \%\end{array}$ & $\begin{array}{c}3.26(1.014) \\
3.06(1.069) \\
p=0.164\end{array}$ \\
\hline $\begin{array}{l}\text { How likely will you be to continue this behavior } \\
\text { change after the term is over? }\end{array}$ & $\begin{array}{l}2010 \\
2011\end{array}$ & $\begin{array}{l}5 \% \\
4 \%\end{array}$ & $\begin{array}{l}8 \% \\
9 \%\end{array}$ & $\begin{array}{l}22 \% \\
17 \%\end{array}$ & $\begin{array}{l}55 \% \\
53 \%\end{array}$ & $\begin{array}{l}11 \% \\
17 \%\end{array}$ & $\begin{array}{c}3.59(0.951) \\
3.71(0.982) \\
p=0.352\end{array}$ \\
\hline $\begin{array}{l}\text { How much did this assignment increase your } \\
\text { interest in helping your patients change their } \\
\text { diet-related behavior? }\end{array}$ & $\begin{array}{l}2010 \\
2011\end{array}$ & $\begin{array}{l}4 \% \\
8 \%\end{array}$ & $\begin{array}{l}12 \% \\
13 \%\end{array}$ & $\begin{array}{l}34 \% \\
35 \%\end{array}$ & $\begin{array}{l}33 \% \\
32 \%\end{array}$ & $\begin{array}{l}16 \% \\
12 \%\end{array}$ & $\begin{array}{l}3.46(1.029) \\
3.27(1.082) \\
p=0.215\end{array}$ \\
\hline
\end{tabular}

Note: Answers range from $1=$ not at all to $5=$ very much, with no verbal descriptors provided for scale points 2,3 , and 4 .

change. Both after two weeks and at the end of the term, the students reported that the exercise had been helpful in making them understand the transtheoretical model of change, ${ }^{31}$ the A-B-C model,,${ }^{30}$ and the motivational interviewing approach ${ }^{32}$ (Table 4$)$.

The final objective was to explore how the students evaluated the exercise and what their behavioral intentions would be concerning continuing their own behavior change as well as engaging their patients in the future in diet-related health education. The majority of the students rated their level of interest in the exercise either as neutral (2010: 49 percent; 2011: 34 percent) or as positive (2010: 27 percent; 2011: 37 percent) (Table 5). Both groups were even more positive about how helpful the assignment was in making them aware of the difficulty of behavior change (2010: 3.48; 2011: 3.29), and the majority indicated that they gained at least an intermediate level of insight into diet-related behavior change through this assignment (2010: 3.26; 2011: 3.06). When asked how likely they would be to continue this behavior change after the term, only 13 percent of the students in 2010 and 13 percent in 2011 indicated that they were not at all or somewhat not likely to continue this behavior change after the term was over, while the majority reported being likely to continue their own behavior change after the term. In addition, when asked how much this assignment increased their interest in helping their patients change their dietrelated behavior, the data showed that the majority of the students were either neutral (2010: 34 percent;
2011: 35 percent) or positive (2010: 49 percent; 2011: 44 percent) in responding to this question, with only a few students indicating that it had not increased their interest in helping their patients (2010: 16 percent; 2011: 21 percent).

\section{Discussion}

Prior research clearly showed that patients' diet-related behavior is integrally related to their oral health. ${ }^{1-16}$ Educating future dental care providers about these issues is therefore important, especially because a survey with practicing dentists found that these providers indicated they would be more interested in educating their patients about diet-related behavior change if empirical evidence supported a relationship between obesity and oral health. ${ }^{19}$ While it is obvious that dental and dental hygiene students need to be educated about nutrition, ${ }^{20}$ one question is how to best educate them about these issues. Integrating this material into the basic, clinical, and behavioral science courses is definitely valuable..$^{24-26}$ However, the question is how to educate them in such a way that it raises the students' awareness concerning the importance of these issues, provides them with the skills necessary to engage their patients successfully in diet-related health education efforts, and ensures that they have the knowledge to do so (Figure 2). If those objectives can be achieved, the humanistic model of professional education ${ }^{34,35}$ 


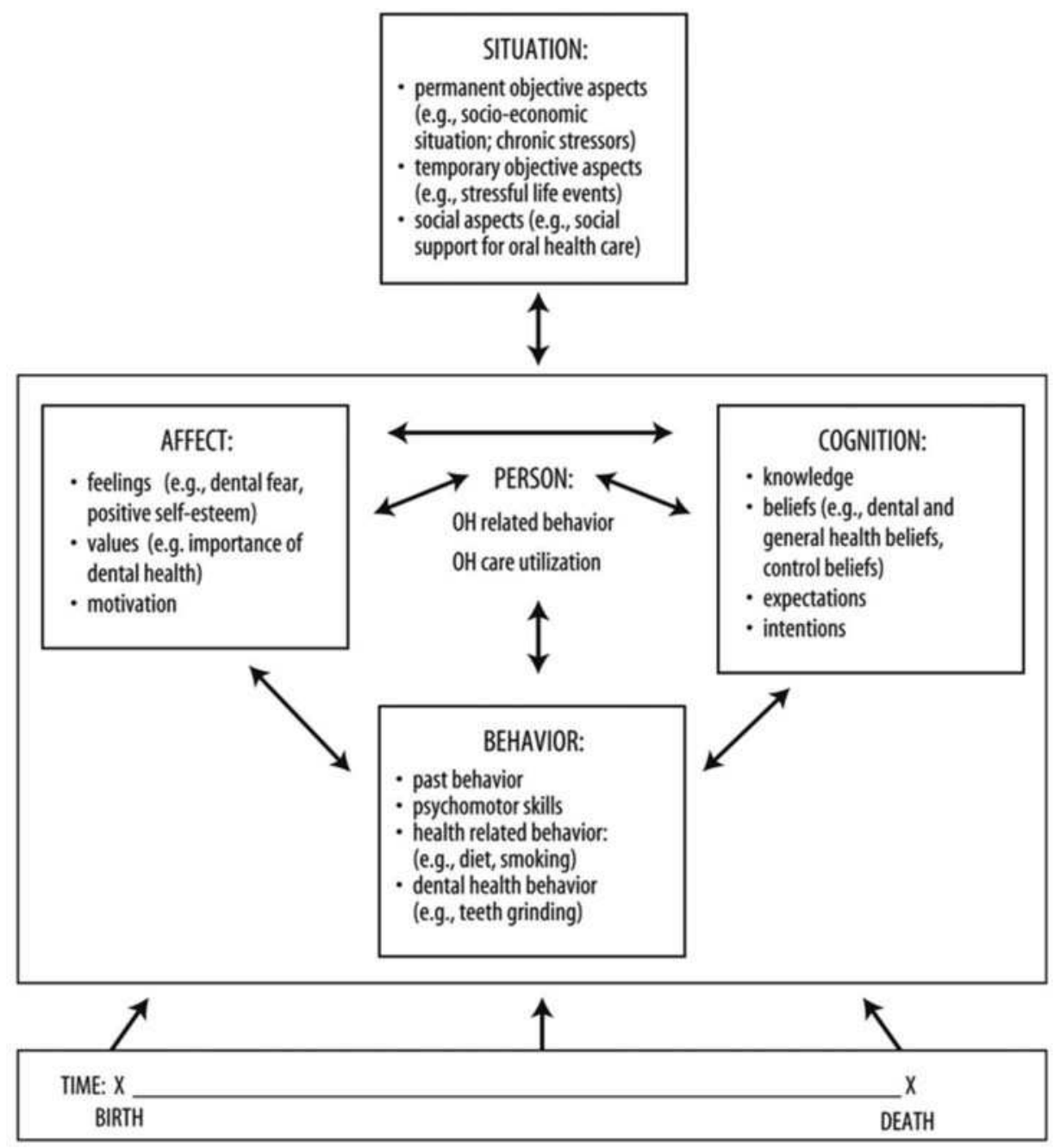

Figure 1. Overview of A-B-C model of behavior change

Source: Inglehart MR, Tedesco LA. Behavioral research related to oral hygiene practices: a new century model of oral health promotion. Periodontol 2000 1995;8:15-23.

would predict that the students then develop a true understanding and expertise and a high level of commitment to engage in these professional behaviors in the future.

An experiential learning exercise was therefore developed with the purpose of creating an educational intervention that would contribute to achieving these goals. It was introduced as part of a nine-week nutrition course for senior dental students and challenged these students to engage in experiential learning about changing their own diet-related behavior. At the beginning of this three-week exercise, the students had to identify one behavior they wanted to change in their own diet. The findings showed that nearly all students could easily identify at least one behavior they wanted to change. Only one student in each year reported having already achieved an optimal diet. However, even these students were able to identify a behavior change that had not yet reached the maintenance stage of behavior change and were willing to engage in the exercise by considering how to move the behavior from the action to the maintenance stage. ${ }^{32}$ Overall, the students in both years agreed at the beginning and throughout the duration 


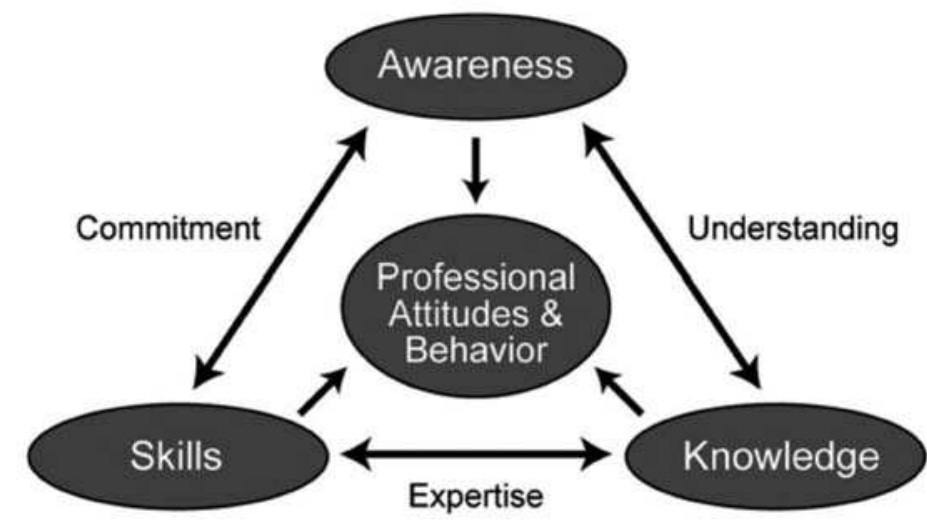

Figure 2. The humanistic model of professional education

Sources: Inglehart MR, Tedesco LA, Valachovic RW. Quality of life: refocusing dental education. In: Inglehart MR, Bagramian RA, eds. Oral health and quality of life. Chicago: Quintessence Publishing, 2002:183-92; and Kanjirath PP, Coplen A, Chapman J, et al. Effectiveness of gloves and infection control: student and provider perspectives. J Dent Educ 2009;73(5):571-80.

of the exercise that it would be important for their own health to change their identified behavior.

In the year in which the exercise was introduced, the students reported at the beginning being less motivated to change this identified behavior than the students in the second year. This difference could be due to the fact that the exercise was new and the students did not think it would be of any benefit to them. However, once they had engaged in the exercise for one week, they became significantly more motivated. Introducing this educational intervention into a course for the first time might have to take into consideration that some students may resist the change. Carefully preparing for introducing a new educational intervention is therefore crucial.

Concerning the students' own diet-related behavior, the data showed that the majority of students identified that they had changed how they thought and felt about this targeted behavior and actually had engaged in behavior change activities. They rated their self-efficacy and their confidence in being able to change the behavior on average as relatively high, and the majority indicated they were likely to continue the behavior change after the term was over. These findings are positive in themselves because they show the positive change brought to these students' own lives through their participation in this exercise.

In addition, the data showed that the students increased their understanding of the concepts of the theories of behavior change as well as their aware- ness concerning how difficult diet-related behavior change is. The majority reported that they had gained insight into diet-related behavior change and that the assignment had increased their interest in helping their patients change their diet-related behavior. Given that behavioral intentions are seen as the best predictor of future behavior, ${ }^{36,37}$ these findings are quite promising.

One lesson learned from this study was that this nutrition course needs to be taught earlier in the curriculum to allow students to enter the clinical phase of their studies with a clear understanding of the importance of these matters for their patients' oral health and a strong motivation to actually engage in this type of health education. As a consequence of these findings, this course has now been moved from the senior year to the winter term of the second year. It will be interesting to follow these students and assess whether they actually will be more likely to engage in diet-related health education with their patients.

However, one important next step in this process of preparing future dental care providers successfully for their engagement in diet-related health education efforts - namely training them in clinical settings-was missing for the students of these two cohorts. This next step was developed and is being implemented in the 2013-14 academic year. After the nutrition course was moved to the second year of the dental curriculum in academic year 2012-13, current considerations center around developing a clinical training module that consists of videotaping 
the students at least once while they engage in these health education activities with patients to ensure that they receive the feedback they need to develop excellent clinical skills in this domain. Introducing this skills training in the clinics is seen as the next step needed to ensure that these future providers will engage in these professional behaviors. ${ }^{38,39}$

Limitations of this research are that no longitudinal data are available to assess whether the students who engaged in this exercise in 2010 and 2011 actually provided diet-related health education for their patients more frequently than students in previous cohorts who had not engaged in the exercise. Future research should focus on assessing the patient-related outcomes of this educational intervention. In addition, it would be powerful to provide the students with more information about their own blood pressure, lipids, and fitness variables, thus allowing them to experientially learn about other health parameters.

\section{Conclusions}

Engaging future dental care providers in an experiential exercise focused on changing their own diet-related behavior had three positive outcomes. It improved the students' awareness concerning their own diet-related behavior and increased their willingness to change their own diet for the better. Second, the students reported that the application of the theoretical models to their own diet-related behavior change increased their understanding of these models. Third, most students saw the value of this exercise and increased their intentions to engage their own patients in diet-related health education efforts.

\section{Acknowledgments}

We want to thank Mira Egbaria, John Anthony Ellenikiotis, Jae Hee Kwak, Dalia Mammo, Krupa Patel, and Allison Petty for helping to code the openended responses.

\section{REFERENCES}

1. Palmer CA. Diet and nutrition in oral health. 2nd ed. New York: Prentice Hall, 2006.

2. Burt BA, Eklund SA, Morgan KJ, et al. The effects of sugars intake and frequency of ingestion on dental caries increment in a three-year longitudinal study. J Dent Res 1988;67(11):1422-9.

3. Moynihan P, Petersen PE. Diet, nutrition, and the prevention of dental diseases. Public Health Nutr 2004;7(1A):201-26.
4. Moynihan P. The interrelationship between diet and oral health. Proc Nutr Soc 2005;64(4):571-80.

5. Kolker JL, Yuan Y, Burt BA, et al. Dental caries and dietary patterns in low-income African American children. Pediatr Dent 2007;29(6):457-64.

6. Ravishankar TL, Yadav V, Tangade PS, et al. Effect of consuming different dairy products on calcium, phosphorus, and $\mathrm{pH}$ levels of human dental plaque: a comparative study. Eur Arch Paediatr Dent 2012;13(3):144-8.

7. Petti S, Simonetti R, Simonetti D'Arca A. The effect of milk and sucrose consumption on caries in 6-to11-year-old Italian schoolchildren. Eur J Epidemiol 1997;13(6):659-64.

8. Johansson I, Holgerson PL, Kressin NR, et al. Snacking habits and caries in young children. Caries Res 2010; 44(5):421-30.

9. Merritt J, Qi F, Shi W. Milk helps build strong teeth and promotes oral health. J Calif Dent Assoc 2006;34(5): 361-6.

10. Duarte PM, Coppi LC, Rosalen PL. Cariogenicity and cariostatic properties of different types of milk-review. Arch Latinoam Nutr 2000;50(2):113-20.

11. Laffranchi L, Zotti F, Bonetti S, et al. Oral implications of the vegan diet: observational study. Minerva Stomatol 2010;59(11-12):583-91.

12. Sherfudhin H, Abdullah A, Shaik H, Johansson A. Some aspects of dental health in young adult Indian vegetarians: a pilot study. Acta Odontol Scand 1996;54(1):44-8.

13. Dye BA, Tan S, Smith V, et al. Trends in oral health status: United States, 1988-94 and 1999-2004. Vital Health Stat 2007;11(248):1-92.

14. Pinto A, Kim S, Wadenya R, Rosenberg H. Is there an association between weight and dental caries among pediatric patients in an urban dental school? A correlation study. J Dent Educ 2007;71(11):1435-40.

15. Julien M. Nutrition: its role in dental training and practice. J Can Dent Assoc 2000;66(2):97-9.

16. Touger-Decker R, Mobley CC. Position of the American Dietetic Association: oral health and nutrition. J Am Diet Assoc 2007;107(8):1418-28.

17. American Dental Education Association. ADEA foundation knowledge and skills for the new general dentist. J Dent Educ 2013;77(7):903-7.

18. Touger-Decker R, Barracato JM, O'Sullivan-Maillet J. Nutrition education in health professions programs: a survey of dental, physician assistant, nurse practitioner, and nurse midwifery programs. J Am Diet Assoc 2001; 101(1):63-9.

19. Curran AE, Caplan DJ, Lee JY, et al. Dentists' attitudes about their role in addressing obesity in patients: a national survey. J Am Dent Assoc 2010;141(11):1307-16.

20. Yuan J, Lee DJ, Afshari F, et al. Dentistry and obesity: a review and current status in U.S. predoctoral dental education. J Dent Educ 2012;76(9):1129-36.

21. Dehghan M, Akhtar-Danest N, Merchant AT. Childhood obesity, prevalence, and prevention. Nutr J 2005;4:24.

22. Thompson DR, Obarzanek E, Franko DL, et al. Childhood overweight and cardiovascular disease risk factors: the National Heart, Lung, and Blood Institute growth and health study. J Pediatr 2007;150(1):18-25. 
23. Braithwaite AS, Vann WF Jr, Switzer BR, et al. Nutritional counseling practices: how do North Carolina pediatric dentists weigh in? Pediatr Dent 2008;30(6):488-95.

24. Wessels KE. Present status of nutrition instruction in dental schools. J Dent Educ 1966;30(1):82-5.

25. Palmer CA. Applied nutrition in dental education: issues and challenges. J Dent Educ 1990;54(8):513-8.

26. Touger-Decker R. Nutrition education of medical and dental students: innovation through curriculum integration. Am J Clin Nutr 2004;79(2):198-203.

27. Lee MM, Wight AJ, Stanmeyer WR. Development and testing of self-instruction programs in nutrition for dental students. J Dent Educ 1981;45(6):344-8.

28. Magliocca KR, Jabero MF, Alto DL, Magliocca JF. Knowledge, beliefs, and attitudes of dental and dental hygiene students toward obesity. J Dent Educ 2005;69(12):1332-9.

29. Conroy MB, Delichatsios HK, Hafler JP, Rigotti NA. Impact of a preventive medicine and nutrition curriculum for medical students. Am J Prev Med 2004;27(1):77-80.

30. Barss P, Grivna M, Al-Maskari F, Kershaw G. Strengthening public health medicine training for medical students: development and evaluation of a lifestyle curriculum. Med Teach 2008;30(9-10):e196-e218.

31. Inglehart MR, Tedesco LA. Behavioral research related to oral hygiene practices: a new century model of oral health promotion. Periodontol 2000 1995;8:15-23.

32. Prochaska JO, DiClemente CC. The transtheoretical approach: crossing traditional boundaries of change. Homewood, IL: Dorsey Press, 1984.
33. Miller WR, Rollnick S. Motivational interviewing: preparing people for change. 2nd ed. New York: Guilford Press, 2002.

34. Inglehart MR, Tedesco LA, Valachovic RW. Quality of life: refocusing dental education. In: Inglehart MR, Bagramian RA, eds. Oral health and quality of life. Chicago: Quintessence Publishing, 2002:183-92.

35. Kanjirath PP, Coplen A, Chapman J, et al. Effectiveness of gloves and infection control: student and provider perspectives. J Dent Educ 2009;73(5):571-80.

36. Fishbein M, Ajzen I. Attitudes towards objects as predictors of single and multiple behavioral criteria. Psychol Rev 1974;81:59-74.

37. Ajzen I. Attitudes, traits, and actions: dispositional prediction of behavior in personality and social psychology. In: Berkowitz L, ed. Advances in experimental social psychology. Vol. 10. San Diego: Academic Press, 1987.

38. Dornan T, Boshuizen H, King N, Scherpbier A. Experience-based learning: a model linking the processes and outcomes of medical students' workplace learning. Med Educ 2007;41(1):84-91.

39. Lee S, Hoerr SL, Weatherspoon L, Schiffman RF. Nutrition students improve attitudes after a guided experiential assignment with older adults. J Nutr Educ Behav 2008;40(5):279-87. 